\title{
ENTREVISTA A BERNARDO RIEGO AMÉZAGA
}

\author{
Interview with Bernardo Riego Amézaga
}

Francisca Comas Rubí ${ }^{\alpha}$ y Bernat Sureda Garcia ${ }^{\beta}$

Resumen. Bernardo Riego Amézaga es profesor de la Universidad de Cantabria. Doctor en Historia Contemporánea, se ha especializado en historia de las imágenes, tema sobre el que ha publicado libros y artículos científicos de referencia. Su formación académica, sus inicios como investigador y docente, su experiencia en el mundo de la comunicación o su paso por la política son informaciones que aparecen en esta entrevista, entrelazadas con sus vivencias personales e irremediablemente unidas a cuestiones sobre las que Bernardo Riego reflexiona, y que abarcan desde aspectos metodológicos relacionados con la interpretación histórica de las imágenes hasta problemáticas actuales que afectan a la investigación y la docencia universitaria.

Palabras clave: Historia de las imágenes; Tecnología educativa; Fotografía; Comunicación audiovisual.

Abstract. Bernardo Riego Amézaga is a professor at the University of Cantabria. He has a PhD in Contemporary History. He has specialized in the history of images, a subject on which he has published reference books and scientific articles. His academic training, his beginnings as a researcher and teacher, his experience in the area of communication or his experience in politics, are information that appear in this interview, intertwined with his personal experiences and irremediably linked to issues on which Bernardo Riego reflects, and they range from methodological aspects related to the historical interpretation of images to current problems that affect research and university teaching.

Keywords: History of Images; Educational Technology; Photography; Audiovisual Communication.

\footnotetext{
a Facultat d'Educació. Departament de Pedagogia i Didàctiques Específiques. Grup d'Estudis d'HIstòria de l'Educació. Universitat de les Illes Balears. Ctra. Valldemossa, Km. 7.5. Palma de Mallorca (07320) Illes Balears. España. xisca.comas@uib.es (D) https://orcid.org/0000-0001-5685-5823

${ }^{\text {B }}$ Facultat d'Educació. Departament de Pedagogia i Didàctiques Específiques. Grup d'Estudis d'HIstòria de l'Educació. Universitat de les Illes Balears. Ctra. Valldemossa, Km. 7.5. Palma de Mallorca (07320) Illes Balears. España. bernat.sureda@uib.es (D) https://orcid.org/0000-0003-2173-3740
}

Cómo citar este artículo: Comas Rubí, Francisca y Bernat Sureda García. «Entrevista a Bernardo Riego Amézaga». Historia y Memoria de la Educación 10 (2019): 597-636 


\section{INTRODUCCIÓN}

Bernardo Riego Amézaga nació en Santander en 1955, es doctor en Historia Contemporánea por la Universidad de Cantabria y actualmente Profesor Titular de Tecnología Educativa y Comunicación Audiovisual de esta misma universidad, donde también imparte Historia de la Opinión Pública en la Etapa Contemporánea y una asignatura sobre la historia de la sociedad de la información para el programa Senior.

Experto en historia de las imágenes, cuenta con numerosas publicaciones sobre este tema que le han convertido en un referente en España. De hecho, nuestro primer contacto con él fue hace ya diez años, cuando recién iniciado nuestro primer proyecto de investigación basado sobre fotografía, le invitamos a participar, junto con María del Mar del Pozo Andrés, en una jornada de trabajo e intercambio de información que resultó muy enriquecedora, sobre todo teniendo en cuenta que en esos momentos para nosotros la interpretación de las fotografías como fuentes era un auténtico reto metodológico. De ese seminario surgió la iniciativa de coordinar un monográfico sobre fotografía e historia de la educación para la revista Educació i Història, en el que Bernardo Riego participó con una interesante reflexión sobre el papel cultural de las imágenes y las posibilidades y dificultades de la fotografía como fuente para la historia. ${ }^{1}$ Una década después sus reflexiones, sus conocimientos y su experiencia siguen siendo un referente para quienes trabajamos con imágenes, motivo por el cual se le invitó a inaugurar el XIX Coloquio de la SEDHE, celebrado en el Escorial en septiembre de 2017, sobre los retos metodológicos actuales que plantea el uso de imágenes, discursos y textos en la investigación histórico-educativa. ${ }^{2}$ Su discurso, siempre sugerente, resultó muy interesante, y puso en evidencia lo enriquecedor que resulta el diálogo entre especialidades diversas.

Esta entrevista pretende dar continuidad a ese diálogo, profundizar en él y hallar más puntos de conexión e interrelación. Se trata de una

\footnotetext{
1 Bernardo Riego Amézaga, «Mirant a la història i aprenent a experimentar amb nous mètodes», Educació i Història 15 (2010), 19-39.

2 Bernardo Riego Amézaga, «Las imágenes como fenómeno cultural: una necesaria mirada en etapas para abordar los retos actuales», en Libro de Resúmenes, XIX Coloquio de Historia de la Educación, Imágenes, discursos y textos en Historia de la Educación. Retos metodológicos actuales (Madrid: Universidad de Alcalá, 2017), 29-30.
} 
conversación entre colegas con intereses comunes, en la que se destilan opiniones, reflexiones y experiencias a través de las cuales no sólo se conocerá mejor al personaje, sino que se entenderá mejor su obra.

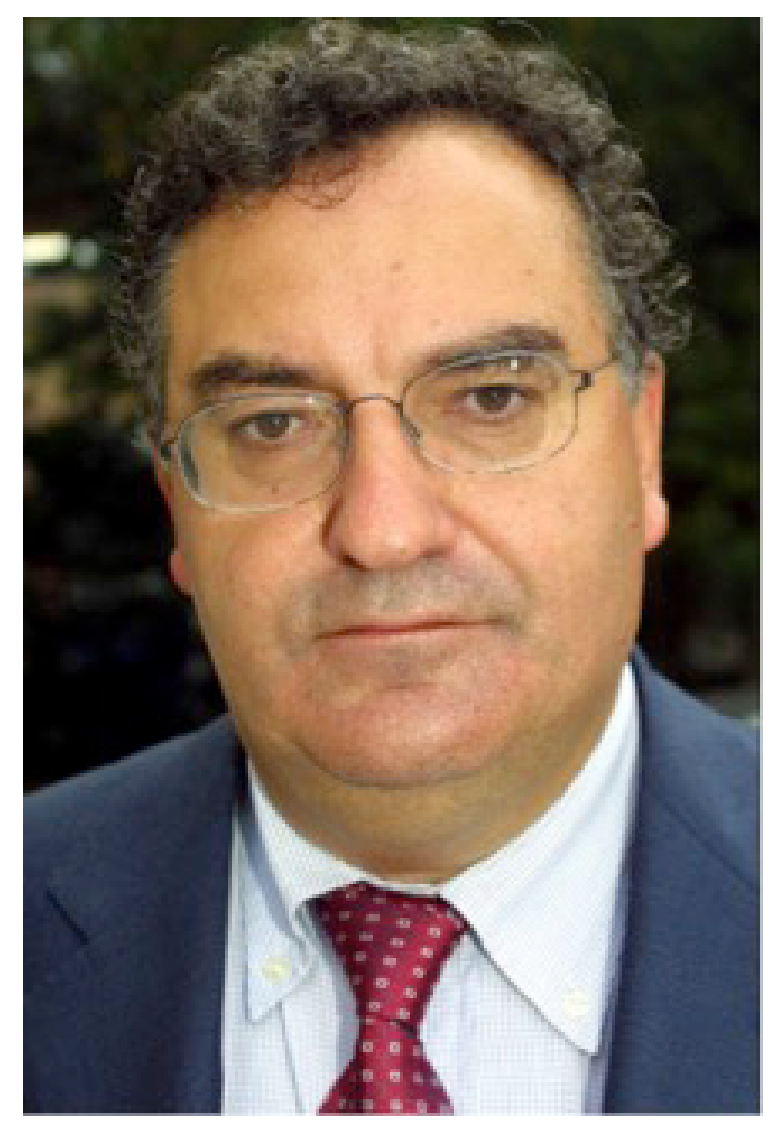

Bernardo Riego, profesor de la Universidad de Cantabria.

- Eres historiador, docente universitario, investigador, experto en historia de las imágenes y la fotografía, pero también en comunicación y tecnología. Tu recorrido académico y profesional se ha caracterizado por una cierta transversalidad, ¿podríamos decir que la Educación ha ocupado un lugar importante en él?

Yo llegué al campo de la Educación en 1981, por pura casualidad, como siempre ocurren estas cosas. El Instituto de Ciencias de la Educación (ICE) 
de la Universidad de Cantabria, un organismo ya desaparecido, había organizado un curso de técnicas fotográficas para la educación y les falló la persona que estaba prevista. Alguien les habló de mí, que en aquellos años era redactor gráfico de un diario local y había realizado algunas exposiciones tanto en Santander como en Madrid, y me llamaron para que me hiciese cargo del taller. Diseñé una actividad muy creativa y atípica usando la fotografía como un instrumento para jugar con las imágenes y reflexionar sobre ellas. La actividad gustó mucho y seguí colaborando esporádicamente con el ICE, sobre todo en sus cursos de verano. En 1984, cuando desaparecieron los medios de comunicación social del Estado, los que estábamos trabajando en los diferentes periódicos pasamos a estar disponibles para trabajar en otros ministerios y centros públicos. Yo me puse a preparar un proyecto sobre imagen turística de Cantabria y me iba a integrar en la Consejería de Presidencia de la incipiente Comunidad Autónoma, organizando un gabinete específico y, en ese momento, me propusieron en el ICE que me fuera con ellos a la también joven Universidad de Cantabria, algo que no me interesó mucho al principio, pues me gustaba más el reto del gabinete fotográfico sobre imagen turística, en un momento en el que no se vislumbraba todavía la digitalidad, pero me había formado en técnicas multimedia y elaboración de contenidos visuales con proyectores múltiples programados, en varios cursos en Kodak, en Madrid y estaba muy al día de muchas de las innovaciones que se estaban dando en el campo fotoquímico y fotográfico. Pensaba que podía hacer cosas muy novedosas. Como la promesa de crear el gabinete se fue demorando, un buen día decidí aceptar ir a la universidad con mi dotación económica, y creo que acerté de pleno sin entonces saberlo. En los años siguientes Cantabria vivió un colapso como comunidad autónoma con aquel pintoresco personaje llamado Juan Hormaechea, que se hizo famoso en toda España por sus extraños comportamientos. Años más tarde cuando fui cargo público con competencias en Industria e Innovación, pude comprobar de primera mano la alargada sombra que dejaron aquellos primeros tiempos y el retraso que supuso para Cantabria aquella nefasta gestión, en una etapa crucial en la que no se aprovechó el enorme tirón que supuso para todo el país la entrada en la Unión Europea, algo que sí supieron hacer muy bien otras regiones. En el ICE, al que llegué finalmente en marzo de 1985, desarrollé como técnico muchas cuestiones relacionados con la formación de formadores, participé en el antiguo 
Certificado de Aptitud Pedagógica (CAP), y le tomé mucho gusto a la Educación aunque, tengo que confesar que siempre me atrajeron más la dimensión técnica y la histórica que la didáctica.

- Hemos mencionado en esta introducción nuestro primer encuentro en Mallorca hace ya una década, ¿qué supuso para ti esa toma de contacto con historiadores de la educación?

El primer contacto con el grupo de Historia de la Educación en 2007, que dio lugar a participar en el monográfico, fue para mí otro momento de encrucijada en mi vida. Acababa de salir de un cargo público. Donde era el segundo nivel en la Consejería de Industria y Desarrollo Tecnológico del Gobierno de Cantabria, había coordinado un montón de competencias y, sobre todo, había aprendido mucho y entendido bastante bien los cambios que se estaban produciendo a nivel educativo, industrial y tecnológico. Para mí la experiencia de los cuatro años del cargo fue un verdadero máster. Y no tenía muy claro qué camino tomar tras el cese que se produjo en 2007. Antes de aceptar el cargo había sido profesor titular interino de Estructura Audiovisual en la Universidad de Extremadura, y estaba (y estoy) muy vinculado a la Universidad Carlos III con el grupo que lidera Antonio Rodríguez de las Heras, un contemporaneista que, ya en la década de los años ochenta, se atrevió a integrar de modo muy pionero en España la informática como un elemento metodológico de la investigación histórica. Antonio, al que siempre he considerado uno de mis maestros, me invitó a integrarme en su universidad, pero había ocurrido algo que había cambiado sustancialmente mi vida, y es que en esos años había adoptado un niño en la India, y entendía que ese tiempo ya era para él, por lo que finalmente activé mi plaza de Técnico Superior en la Universidad de Cantabria y me quedé en Santander.

Fueron en esos momentos en los que estaba decidiendo qué hacer, cuando entré en contacto con el grupo de Historia de la Educación, y creo que ese encuentro me reforzó en la idea de que tenía que seguir en una línea que yo había cultivado siempre, y es la de ser transversal en mi investigación. En aquellas jornadas en Palma de Mallorca descubrí un grupo de historiadores muy rigurosos e interesantes, que además reforzaban una de las cuestiones que ya había descubierto cuando hice mi tesis doctoral, que leí en 1998, y era que faltaban instrumentos de análisis de las imágenes como fuente histórica, pero que eso no era una 
limitación a priori si el historiador tenía un buen conocimiento de su temática. Recuerdo con mucho cariño aquel encuentro y el monográfico en el que participé. Y cuando me invitaron, en 2017, a los Diálogos de Educación en San Lorenzo del Escorial, comprobé que en esos diez años había emergido un potente grupo de historiadores de la educación usando las imágenes como conocimiento histórico. Por cierto, Juan Carlos Cubeiro, uno de los mejores expertos en coaching que tenemos en España y buen amigo mío, dice que diez años es el tiempo óptimo para alcanzar la excelencia en un proyecto. Y en el caso de los historiadores de la educación y el uso e interpretación de las imágenes, de nuevo se ha cumplido esa premisa.

- Debería haber más relación entre investigadores de diferentes ramas sectoriales de la Historia...

Creo que los sujetos y focos de atención de la Historia se han ensanchado tanto en las últimas décadas que cualquiera de nosotros tiene que estar atento a temáticas de las que posiblemente conocemos poco en un momento determinado, pero gracias a la circulación del conocimiento podemos aprender con facilidad. El saber no es exclusivo de nadie, ni es coherente en estos momentos defender posiciones cerradas en cuanto a las especialidades que uno conoce. En el caso de las imágenes hay una premisa básica; dada la influencia de los imaginarios en las sociedades contemporáneas se hace difícil obviar su presencia en los estudios históricos. Del mismo modo que un contemporaneista no puede eludir la existencia de nuevas fuentes no escritas para el periodo objeto de estudio, y que están ahí esperando su interpretación historiográfica.

- Háblanos de tu formación académica, ¿por qué decidiste estudiar Historia?, ¿cómo te interesaste en concreto por la historia de las imágenes $y$ de la fotografía?

Existe un término que tiene una connotación despectiva en estos momentos y es el de "puerta giratoria», pero yo siempre he defendido que una de las potencialidades de la Universidad es que puedes entrar a ella, o salir de ella para hacer otras cosas, cuando creas que es el momento oportuno, que el valor de la institución siempre está ahí y que además de formación te permite cristalizar y madurar tu conocimiento y también los valores personales. 
En mi caso, terminé el Curso de Orientación Universitaria (COU) en 1973 y fui de la primera promoción que ya no tuvo el curso Preuniversitario; en mi orientación universitaria me recomendaron estudiar Periodismo o Historia, y me decidí por periodismo. Llegué a matricularme en la Complutense para el curso siguiente, pero por razones familiares y económicas no pude ir a Madrid; estaba trabajando y mi aportación económica era fundamental en mi casa. Había entrado en 1971 a trabajar en un periódico de Santander y me tuve que quedar. Más tarde en la década de los años ochenta me matriculé en la Universidad Nacional de Educación a Distancia (UNED) en Derecho y cursé asignaturas sueltas hasta tercero, pero mi actividad era frenética y no tenía tiempo ni espacio de concentración, aunque esa información inconclusa me dio un buen fondo de razonamiento que siempre he agradecido. Así que cuando, en 1985, llegué a la Universidad de Cantabria, tenía pendiente de resolver mi formación universitaria. Al principio seguía pensando en periodismo y hacerlo en la Universidad del País Vasco, pero conocí al grupo de Historia Contemporánea de la Universidad de Cantabria, me gustaron mucho las clases de metodología de la profesora Ángeles Barrio Alonso, e intuí que debía cambiar mis planteamientos. Acerté de pleno, porque fue una experiencia magnífica para mí, además yo tenía más edad que los alumnos regulares, era más maduro y valoraba mucho lo que significaba la universidad. Mi esposa que tampoco había tenido oportunidad de hacer estudios superiores en su momento y como yo comenzó a trabajar muy joven, también se matriculó en la universidad, éramos de una generación que muchos no habíamos tenido la suerte de hacer estudios superiores cuando nos tocaba. Ahora hay muchos graduados superiores, pero en nuestra juventud no era así. Yo me acuerdo de que, haciendo la carrera y queriendo estudiar en verano para ir venciendo asignaturas, tras dirigir un curso de fotografía histórica y metodología en los cursos universitarios en Laredo, me fui con mi esposa a la Unión Soviética de vacaciones; era el verano de 1988, y yo llevaba los apuntes de prehistoria que estudiaba durante el viaje y mi esposa los de relaciones laborales. Fueron años intensos que merecieron mucho la pena y abrieron todo lo que vino después.

Tengo que decir que la Historia me ha dado mucho en todos los sentidos. Para la tesina me concedieron una beca de investigación que me permitió ir al Instituto de Francia en París y a la Academia de Ciencias 
de Barcelona. De esa investigación salió mi libro sobre la recepción de la fotografía en España por la generación intermedia de los científicos liberales isabelinos, una defensa que estuvo presidida nada menos que por Luis García Ballester, uno de los discípulos de José María López Piñero. Tras mi buena experiencia investigadora, entendí que tenía que hacer la tesis y además en un departamento que se dedicaba ya entonces a la Historia Política de la Restauración y donde tenía que demostrar que trabajar con imágenes históricas no era nada anecdótico, sino una posibilidad fundamental en una disciplina que por su marco temporal no podía seguir obviando las nuevas fuentes documentales de la contemporaneidad. Tuve la suerte de contar con la comprensión de la profesora Ángeles Barrio Alonso, con la que tengo una profunda deuda intelectual y personal, y así lo he dejado escrito en alguna ocasión. Ella me ayudó a clarificar las ideas, a pasar de la inmediatez periodística, a la que estaba acostumbrado y muy entrenado, a la pausada reflexión de la historiografía, a integrar otras ideas y pensamientos y, sobre todo, a ser muy riguroso. De nuevo tuve la suerte de que me concedieron una generosa beca de investigación lo que me permitió visitar centros documentales y hacer estancias que me fueron muy útiles. Experimenté técnicas muy innovadoras para integrar las imágenes en el trabajo histórico, y no solo en lo metodológico sino también en lo técnico. Con un disquete de tres y medio pulgadas, de aquellos que usábamos para guardar los textos, desarrolle una técnica que me permitía cargar en ordenadores diferentes el disquete y, cuando lo hacía, se integraban las decenas de imágenes de los capítulos en la pantalla del ordenador y podía trabajar con ellas. Digitalicé los microfilmes que iba obteniendo en los centros documentales, aprendí a exprimir los ficheros pdf, que entonces eran muy desconocidos y más con imágenes integradas, y el resultado fue espectacular. Tuve un tribunal de lujo y transversal presidido por José Álvarez Junco, con Antonio Rodríguez de las Heras, María de los Santos García Felguera, Mario Díaz Barrado y Germán Rueda, que debatieron entre ellos sobre la pertinencia del uso de las imágenes en historia con la propuesta que presentaba. Corría el año 1998...

- Sabemos que en Cantabria, anteriormente a tu actividad universitaria, ejerciste el periodismo gráfico, ¿qué aporta al análisis histórico de la fotografía el hecho de haber estado detrás del objetivo?

El periodismo gráfico fue una actividad en la que estuve hasta 1985, y lo que más aprecio de ella es la posibilidad que te da de conocer lo que 
yo llamó «la realidad en capas». A las 9 de la mañana puedes estar haciendo fotos de un accidente con todo el entorno llorando y desquiciado, dos horas después vas a una rueda de prensa en la que todos son felices y corteses y al final de la mañana intentas fotografiar en el juzgado a un pobre desgraciado que tras beberse una botella de coñac ha asesinado al entrenador del equipo de su hijo porque no le alineaba para los partidos, y acabas el día en la presentación de un libro, un coctel, o cualquier otro tema muy diferente a los anteriores. Esa variedad de entradas en la realidad de tu entorno te permite tener una visión en «capas» del día a día. Ahora bien, es una profesión agotadora que no te deja tiempo para reflexionar. Ayer te jugaste el tipo subido a un tejado para obtener una buena foto que han publicado en primera página a cuatro columnas, y cuando la imagen sale impresa ya estás en otro tema totalmente diferente.

Es una profesión en la que se envejece muy mal, lo hablaba un día con mi colega de la Universidad del País Vasco, Ramón Esparza, que fue redactor gráfico como yo en fechas parecidas. A mí me tocaron todos los inicios de la transición en Cantabria, y poco a poco fui también escribiendo. De hecho, mis primeros textos sobre historia de los fotógrafos santanderinos los publiqué en las páginas centrales de mi periódico, donde entrevisté entre otras a Susan Sontag, fotografié a Borges cuando estuvo en la Universidad Internacional «Menéndez Pelayo» y conocí a personas que me han dejado huella como Ignacio Ellacuría, poco tiempo antes de que lo asesinaran, y me sorprendió su enorme lucidez y valentía personal ante la realidad salvadoreña. Fueron unos años magníficos que me dieron algo que todavía tengo, y es mi obsesión por conectar con quien me lee. Me interesa mucho entender a quien le interesa mi trabajo y como puedo «engancharle» desde las primeras líneas. Me viene de esa época profesional y también de mi admiración a historiadores como Ernst Gombrich, que era un maestro en eso de aproximar a sus lectores a cuestiones complejas con la mayor simplicidad del mundo.

- Pasando a tu labor académica, has sido profesor en la Universidad de Extremadura y en la de Cantabria. ¿Puedes explicarnos un poco tu carrera profesional?

Si tuviera que explicar mi carrera profesional, empezaría diciendo que ha sido tan intensa como zigzagueante. En la universidad aporté 
conocimientos y prácticas que no estaban a la vez que me hacía día a día con ese espíritu universitario que tanto me gusta, y quiero que sea siempre una de mis señas de identidad. Cuando terminé la licenciatura en 1990, mi orientación a la docencia universitaria era ya clara. Eran los tiempos de la Ley de Reforma Universitaria (LRU) y había más flexibilidad que ahora. En mi caso yo estaba en una paradoja curiosa: por un lado, al ser Técnico Superior tenía una muy buena remuneración, y como hacía muchas cosas vinculadas a la docencia, no tenía prisa por cambiar mi situación, sobre todo viendo a compañeros, de situación laboral más precaria, que estaban a la espera de consolidarse en la universidad y yo ya lo estaba de algún modo por mi inusual procedencia. Sabía que algún día sería el momento y que tenía que aprovechar para formarme muy bien. Gozaba de Venia Docendi, me otorgaban becas de investigación, daba clases en Educación y en Historia, dirigía proyectos sobre recuperación de imágenes históricas en ayuntamientos..., porque llevaba una unidad de digitalización de imágenes muy pionera. Por ejemplo, durante dos años impartí en la Facultad de Historia una asignatura denominada «Informática para Historiadores», porque el titular estaba en excedencia por un cargo público. Y en aquellos años participaba en los cursos formativos que organizaba el ICE, lo que me permitía desarrollar muchas cuestiones novedosas que interesaban a los formadores, enseñaba técnicas docentes con audiovisuales a los nuevos profesores de la Universidad de Cantabria, dirigía en el Vicerrectorado de Extensión un Aula de la Fotografía y de la Imagen donde invitábamos a expertos nacionales de primer nivel y donde en 1993 comenzamos a formar en fotografía digital. A partir de 1998, en los cursos que impartía en el Aula los alumnos podían pedir la convalidación como cursos externos de doctorado por mi titulación. Realmente abrí muchos caminos nuevos mientras fui consolidando mi investigación en las imágenes como fuente histórica. No tenía prisa por cambiar de técnico a docente y dejaba que todos pasaran antes que yo. Yo creo que formo parte de una generación que era consciente de que estaba todo por hacer y nunca he tenido miedo a los nuevos retos, es más, me encantan. Hago siempre una broma con el título de un libro del neodarwinista Richard Dawkins, «El gen egoísta», diciendo que, en mi caso, lo que tengo es un "gen insensato». Por ejemplo, un día, en 1992, el rector de entonces, José María Ureña, me encontró en el Rectorado y me dijo que estaba pensando abrir una sala de exposiciones para dar visibilidad a la Universidad de Cantabria y 
que había pensado en mí para dirigirla; por supuesto, le dije que sí y me encontré ante un reto en el que aprendí de nuevo mucho, y no hace tanto he reflexionado sobre la escritura expositiva sobre la que he escrito un capítulo en un libro sobre Gestión del Patrimonio Fotográfico, editado por Antonia Salvador Benítez y publicado por Trea.

Pero en el año 2000, se produjo una de esas situaciones habituales en nuestra "selva» universitaria. Se iba a crear una titulación en Historia del Arte, que al final no se aprobó y el rector de entonces, apoyó que se me convirtiera en Titular de Universidad en el área de historia del cine y otros medios, tras pasar, por supuesto, una oposición normal y corriente y aprovechar mi dotación económica. Creía que contaba con el apoyo de los profesores de Historia del Arte con los que colaboraba e incluso impartía cursos de doctorado y ellos me habían animado a pedirla. La plaza que iba con todas las bendiciones, como solemos decir en la jerga universitaria, desapareció de las peticiones del Departamento por las maniobras oscuras de tres personas que a la vez que públicamente me apoyaban, decidieron beneficiar a un amigo suyo. En aquellos momentos estaba dando clase como asociado en el Grado de Magisterio, y me ocupaba de los cuatro grupos de Tecnología Educativa porque su titular estaba también en un cargo público; esto lo hacía sin remuneración complementaria y atendiendo a la vez mis funciones de técnico. Me dolió mucho lo ocurrido, a sabiendas de que es algo al que no soy el único al que le ha pasado, y recordé entonces que hacía ya algún tiempo que Mario Díaz Barrado me había comentado que se había creado una Facultad de Comunicación Audiovisual en Extremadura y que si lo deseaba allí tenía sitio. Recuerdo que tuve una extensa e intensa reunión con el Rector de la Universidad de Cantabria que, por un lado, comprendía mi enfado, pero que le parecía que debía tener un poco más de paciencia y quedarme. Al final me fui y pasé dos años intensos y maravillosos en la Universidad de Extremadura, como titular interino LRU en Estructura Audiovisual. Allí estuve hasta 2003, y cuando me quise dar cuenta mi vida había cambiado; mi familia con el nuevo hijo, pugnaba porque volviera a Santander, yo realmente quería irme a Madrid a la Carlos III, y una mañana cuando iba a un seminario de Badajoz a Madrid sonó el teléfono a la altura de Bailén donde aparqué el coche, porque entonces no había manos libres. Era un amigo y colega de la Universidad de Cantabria, Miguel Ángel Pesquera, presidente entonces del Puerto de Gijón, 
que le acababan de nombrar consejero de Industria, Trabajo y Desarrollo Tecnológico en el Gobierno de Cantabria, y me invitaba a ser su segundo y a desarrollar las competencias de Desarrollo Tecnológico e Innovación, además de ser el secretario general de la consejería. Tras hablarlo en casa acepté y volví a Santander. Estuve cuatro años en el cargo y ha sido una experiencia que me ha marcado mucho y me ha dado una visión muy extensa y tolerante de la realidad. Soy de los que piensan que en algún momento deberíamos ser gestores públicos y luego poder volver tranquilamente a tu profesión. Lo ideal es estar entre cuatro u ocho años, como máximo, no perder el contacto con la realidad ni abandonar tus conocimientos personales y profesionales. Fueron unos años en los que apenas publiqué, pero en los que estuve en situaciones que nunca hubiera conocido en mi devenir habitual. Viajé mucho a China y a Latinoamérica, dirigí un potente programa de europeo de implantación social de la digitalidad, experimenté la soledad del coche oficial, trabajé mucho y sin fines de semana, aprendí a ser muy tolerante con las visiones de los demás y en general fueron unos años excepcionales, pero ahora ya no volvería de nuevo a un cargo público si me lo ofreciesen. Pero es cierto que ahora entiendo de aspectos tecnológicos de los que antes no sabía nada. Lo que me ha dado la triple experiencia de ser tecnólogo como usuario, como profesor universitario y como gestor público, lo que es una intersección muy interesante y poco habitual. Aunque ahora la actividad política tiene muy mala imagen, es cierto que hay muchísimas personas honradas que trabajan mucho; también es cierto que hay personas sin formación adecuada que han hecho carrera de lo público y aguantan lo que sea y a quien sea y toman decisiones importantes sin apenas conocimientos y he comprobado que la estructura creada en torno al poder político está muy parasitada, algo que ves muy bien desde dentro. De todos modos, tengo recuerdos inolvidables de una etapa que fue para mí extraordinaria, pero ahora lo que me gusta y disfruto es mi actividad docente e investigadora en la Universidad de Cantabria a la que de nuevo volví en 2007 y en una ciudad, Santander, donde he visto crecer a mi hijo, algo que para mí está siendo impagable.

- Cierto que la actividad política no goza de buena fama en estos momentos, aunque tú siempre has defendido el buen ejercicio de la misma...

Creo que la actividad pública y política debería ser una experiencia más extensa para muchas personas, porque te da una visión muy buena 
de cómo funcionan las cosas. Creo también, ya lo he dicho, que no debería nadie quedarse en política más de ocho años y todo el mundo que está en un cargo debería volver a su profesión. Si no te preparas bien mentalmente, acabas aislado de la realidad y luego la vuelta es durísima para muchos. Yo he conocido bien la experiencia los cuatro años que estuve y hay algo que a pesar de toda la impresión actual y generalizada me gustaría decir: España no es un país corrupto. De hecho, ninguno de nosotros para que nos hagan una gestión en una oficina pública, tenemos que deslizarle al funcionario que está allí, un billete de 20 o 50 euros, algo que en algunos países asiáticos y latinoamericanos sí sucede todavía. En alguna ocasión me tocó estar con los interventores que mandaban de Bruselas del Fondo Social Europeo para revisar nuestras cuentas, y reiteraban que lo que se evaporaba de los recursos que se enviaban a España no era significativo a diferencia de lo que ocurría en algunos países del Este, por ejemplo. Con la crisis de 2008 ha aparecido una realidad muy diferente y estamos asistiendo a un escándalo tras otro, pero yo creo que el fallo genérico está en una de las sombras del sistema de la Transición y de nuevo, para explicarlo, acudo a mi experiencia de historiador y de gestor público para compartir mi reflexión.

El funcionariado español no es corrupto, los sistemas de intervención son bastante eficientes, salvo en las empresas públicas, que es una estructura que se rige por otras normas y ahí donde suelen aparecer generalmente los agujeros en las tramas corruptas. Pero realmente donde no se hicieron las cosas bien en la Constitución del 78 fue en no poner a costes el sistema político. Me explico; basta mirar lo que los partidos declaran al Tribunal de Cuentas de cada gasto electoral y lo que recaudan por actas, número de votos, etc., etc., para darte cuenta de que hay un desfase de gastos e ingresos que los partidos tienen que buscar en otro lado, y ese otro lado son las empresas que concursan. Por algún motivo, el nuevo sistema político de la Transición no se atrevió a decirle a la ciudadanía que una democracia es mucho más cara que una dictadura, y tal vez que como europeos no teníamos que haber entrado en esa cultura de campañas electorales americanizadas que son carísimas y obligan a los partidos a buscar incesantemente recursos fuera de los cauces institucionales. Cuando veo en los informativos esos minutos de mítines los fines de semana, o convenciones montadas de tanto en tanto 
para mantener el nivel de movilización de los afiliados, ese tiempo realizado, que los partidos entregan a las cadenas de televisión, y estas lo pasan como información siendo propaganda, son espectáculos políticos que cuestan mucho dinero, y ahí aparecen unos personajes siniestros que son los recaudadores, que están en todos los partidos y, si se los pilla, la consigna es mirar para otro lado y decir que son casos aislados, pero lo cierto es que la corrupción es inherente al sistema por un incorrecto diseño inicial del sistema del 78 , y eso es algo que la ciudadanía debería exigir a los partidos que lo corrigiesen de verdad, porque todos ellos lo saben y lo usan, aunque finjan que es casual y que lo desconocían cuando se descubre algún caso.

He conocido a muchas personas en cargos públicos y mi experiencia es que la mayoría son muy honrados sin distinción de color político, y hay otra realidad que yo he conocido y también debería ser mejorable. En mi cargo coordinaba y gestionaba casi doscientos millones de euros al año, y de repente tenías una actuación necesaria que, con las velocidades de gestión de la administración general, corrías el riesgo de que no se ejecutase presupuestariamente y lo perdieras en detrimento de la ciudadanía. Una solución era abrir una empresa pública puntual y finalista para poner en marcha una actuación, por lo general nueva y sin precedentes en el sistema de gestión. Una vez que conseguías los informes jurídicos y fiscales favorables, te ponías a buscar a una persona con perfil profesional idónea para ejecutar, pongamos, por ejemplo, una actuación en administración electrónica en dos años. Y ahí de nuevo aparecía un nuevo problema. Por las remuneraciones públicas que están tasadas si querías contar con alguien muy capacitado del sistema privado, lo habitual es que estuviese cobrando el doble de lo que tú podías ofrecerle y declinaba aceptar. Pero eso sí, siempre tenías en el partido de turno, fuera el que fuera, a alguien sin los estudios adecuados pero disponible que se postulaba de inmediato. Desde un punto de vista de eficiencia de los recursos públicos, los cargos están mal remunerados para los profesionales que lo harían muy bien y le ahorrarían muchos recursos a la ciudadanía con su profesionalidad y experiencia, pero excesivamente pagados para personas que se han hecho costra en los partidos políticos y perviven como sea, y se ocuparán de todo lo que puedan porque nunca obtendrían esas remuneraciones en su tarea profesional. Con todo, creo que la experiencia de la gestión pública es muy 
interesante; yo nunca entré con vocación de quedarme, pero agradezco mucho todo lo que he aprendido de mi paso por la política, me han quedado algunos amigos y como ya dije, la experiencia me ha marcado mucho.

- Volviendo a tu carrera profesional universitaria, como docente, ¿qué tipo de materias has impartido y cuál ha sido tu experiencia personal y profesional?

He impartido asignaturas en varias áreas de conocimiento (Historia, Bellas Artes, Educación), siempre de temas vinculados a la imagen y la tecnología. Resalto algunas. En Historia, como he contado antes hice «informática para historiadores» durante dos años, en Educación, además del CAP donde impartía técnicas de imagen, fui responsable de la asignatura Tecnología Educativa para las cuatro especialidades que había entonces. También he impartido algunas asignaturas en universidades catalanas como Historia de la Fotografía en una especialidad que se creó en la Universidad Politécnica de Cataluña, y ahora cada dos años, más o menos, imparto dos asignaturas on-line en un posgrado de documentación fotográfica en la Universidad Autónoma de Barcelona, además de las que imparto regularmente en la Universidad de Cantabria que versan en Educación sobre Innovación y Tics para la especialidad de educación primaria y las Tics en la Educación para la especialidad de Educación Infantil. Además, en el Máster Interuniversitario de Historia Contemporánea imparto una Historia de la Opinión Pública que parte del sistema informativo liberal del siglo XIX hasta la actual sociedad-red, y en el programa Senior de la Universidad de Cantabria estoy con una asignatura en la que vemos con perspectiva histórica la evolución del pensamiento digital desde el auge del capitalismo en el siglo XVI, hasta el Internet Cognitivo que está a punto de llegar, y estoy diseñando una asignatura que tengo muchas ganas de abordar y es la cuestión de los contrafactuales, desde la econometría pasando por el cine y la literatura, entre otros. Realmente mi red invisible en la universidad abarca muchas áreas de conocimiento como Documentación, Bellas Artes, Historia, Educación, Historia del Arte, etc., etc. He impartido muchos cursos de doctorado en varias universidades y he estado en tribunales de tesis de diversas áreas de conocimiento. Nunca he tenido miedo a la transversalidad, aunque reconozco que dificulta mucho el desarrollo de la carrera profesional, porque nuestro esquema se sustenta en la referencia a una 
sola área concreta de conocimiento, lo que no se corresponde a la situación actual de la cultura y la sociedad.

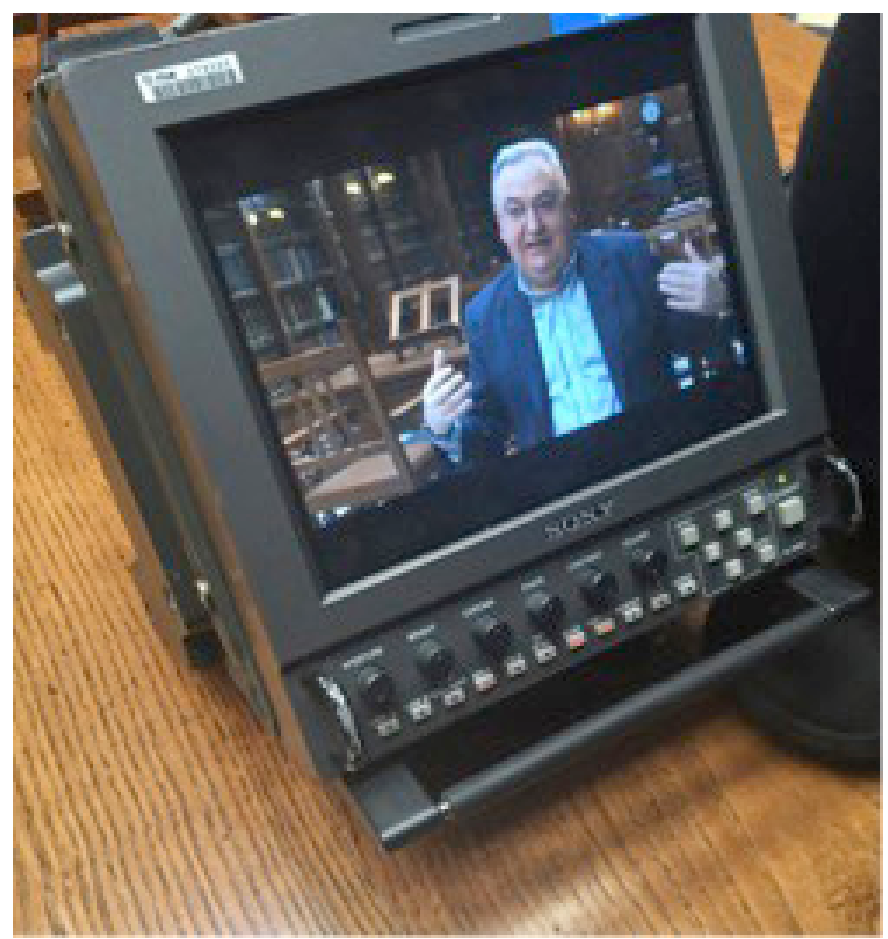

Bernardo Riego en la Biblioteca Menéndez Pelayo de Santander entrevistado para el programa de TVE «Cartas en el Tiempo» (abril 2018) (Foto Javier Riego).

- Has mostrado siempre gran interés en relacionar tecnología, educación y sociedad, ¿puedes darnos tu punto de vista al respecto?

Cuando comencé a trabajar con imágenes como fuente histórica, me di cuenta enseguida de que nuestra formación orientada a un solo campo de conocimiento no nos permitía aprovechar la potencialidad narrativa y documental de las imágenes como fuente de la Historia. Comprendí pronto que la Cultura es un complejo que se extiende en muchas direcciones y que, por ejemplo, para entender la construcción de una determinada imagen histórica, hay que trascender esa concreta representación y entender el imaginario cultural de un tiempo concreto que se relaciona con las imágenes, pero sin duda con la literatura, con el cine 
y con todos los materiales culturales y sociales que conforman la realidad. Ese es el reto que tenemos, en mi opinión. He escrito mucho sobre esta cuestión y animo a los historiadores a salirse de la zona de confort de su ámbito central de conocimiento. Esa transversalidad en la que creo y práctico, me ha supuesto situaciones muy divertidas; a mí se me encuadra generalmente en historia de la Fotografía, pero a la vez estoy en un grupo de investigación que lidera el profesor Ángel Quintana desde la Universidad de Girona sobre orígenes del cine mudo en España, o me invitan a congresos sobre grabado y estampa porque me han interesado los aspectos de continuidad cultural de ambas técnicas de representación visual. Hace unos años hubo un congreso sobre el grabado del siglo XIX en San Sebastián, organizado por el Museo Zumalacárregui en el que estaba invitado como ponente y también lo estaba Elena de Santiago, una referencia en Historia del Grabado en España a la que admiro mucho. Elena, con la que me une una gran amistad, al verme me dijo con humor: «Bernardo, ¿qué haces aquí?, si tú eres de fotografía». No hace mucho me volví a encontrar con ella en una sesión sobre Humanidades Digitales que organizaba la Biblioteca Nacional y me reiteraba esa disposición a la transversalidad que forma parte de mi forma de trabajar.

- Como docente e investigador universitario, ¿cómo valoras los cambios producidos en la universidad desde que empezaste hasta hoy?

La universidad que yo conocí en la época de la LRU, no es ya la actual, con eso no quiero decir que aquella era excelente y la de ahora no. Creo que el plan Bolonia nos ha hecho más cercanos a las necesidades de las sociedades complejas y avanzadas actuales, y que los nuevos profesores tienen otras exigencias. Como aspecto no resuelto en estos momentos, está todo el sistema de valoración de la investigación, que obliga a los jóvenes a trabajar en temas que en ocasiones no les interesan, y como estructura humilla mucho a los investigadores universitarios porque el sistema de valoración que se ha impuesto en España tiene parámetros en los que se da más importancia a la forma cuantitativa que al fondo cualitativo. Además, todo este tema de los papers que se ha implantado ha creado un negocio mundial paralelo de veinte mil millones de dólares que beneficia a unas pocas empresas externas al sistema universitario, empresas que se han montado y se están beneficiando de las necesidades de publicación indexada necesarias en estos momentos por 
una aplicación no muy fina del sistema de evaluación que tenemos. Una problemática que está cada vez más estudiada y que, evidentemente, obvia la pasión por investigar y dar a conocer aspectos desde el propio compromiso profesional y personal del conocimiento adquirido, y solo atiende a los aspectos cuantitativos que son más fáciles de valorar, sin duda. Con muchos colegas docentes con los que he hablado, tienen alguna experiencia negativa respecto a la valoración de los sexenios de investigación; la mayoría ha perdido algo en el camino. Yo estoy ahora con el tercero y espero pedir el año que viene el cuarto porque me están evaluando todo el trabajo anterior. Pero en mi caso el primero fue muy humillante. Por inexperiencia no especifiqué bien el campo de evaluación y cayó en Bellas Artes, evaluadores de Dibujo que me dejaron por cuatro décimas fuera a pesar de tener artículos internacionales en revistas de referencia en un campo nuevo como es la Historia de la Fotografía, y que no valoraron, seguramente porque no sabían qué eran o porque aplicaron una inexistente plantilla. Con todo creo que la universidad tiene que ser un instrumento de modernización social, responder a las necesidades del momento y tener una visión de nuestro trabajo que conecte con esa red invisible y necesaria que es el conocimiento sin corsés localistas. A mí me fascina mucho la intensa presencia de los jóvenes profesores en muchos congresos internacionales en estos momentos, y la movilidad en ese sentido que tienen, pero también es cierto que la Ley Orgánica de Universidades (LOU) ha precarizado mucho la carrera docente de los más jóvenes. Cuando estaba en el cargo público, entonces veía a la universidad como una estructura también de gasto de recursos; en relación con sus resultados, tenía una metáfora, bueno dos, que me parecen interesantes: una universidad como la de Cantabria, por poner un ejemplo, entre la dotación inicial de su contrato-programa y los proyectos que va consiguiendo, tiene disponibles unos cien millones de euros cada año más o menos. Pero la siguiente cuestión es ¿cuánto de esa masa de recursos se transfiere al sistema industrial, productivo, social, de modo tangible o intangible? Y ahí es donde aparece, por comparación, la metáfora de la primera revolución industrial en la que solo el cinco por ciento del carbón que se vertía en las calderas se transformaba en vapor. Algo así ocurre con nuestro sistema de conocimiento. No estoy defendiendo la idea neoliberal de que la universidad debe ser una máquina eficiente y entrenada para responder solo a las necesidades del sistema productivo. Para nada. Hay conocimiento básico que hay que 
transmitir a las nuevas generaciones, hay muchas cuestiones de visibilidad universitaria que no están en el simple conocimiento, y lo digo con la experiencia de alguien que ha hecho gestión en extensión universitaria. Existe, al mismo tiempo, una visión deformada del valor, por ejemplo, de las humanidades. Y ahí va mi segunda metáfora: con todo mi respeto a ingenieros y a economistas, quienes mejor estamos preparados para entender la complejidad de nuestras sociedades y nuestro tiempo somos los historiadores y los humanistas. A diferencia de otras disciplinas, nosotros no trabajamos sobre la cuadrícula, sino que somos capaces de organizar desde el caos, como lo hacemos con los documentos que analizamos a los que damos un sentido historiográfico coherente. Existen corporaciones de gran tamaño y complejidad como Microsoft en las que sus recursos humanos, por ejemplo, los lleva una persona formada en Historia Contemporánea, y yo experimenté en mi caso de gestión pública de una consejería, que partiendo de una visión humanística que entiende la tecnología, se está mejor armado para gestionar estructuras complejas y diversas. En mi caso, tuve responsabilidad sobre quinientas personas y mi esquema mental de historiador me fue siempre de gran utilidad para entender los contextos y las texturas de los problemas. Estoy con Ken Robinson cuando dice que tenemos que repensar la jerarquía de los conocimientos, y los humanistas estamos en la mejor posición para entender los profundos cambios que se están produciendo, a pesar de que parece que este es mundo de ingenieros y economistas, pero Nassim Taleb, el autor de la teoría de la incertidumbre publicó en 2010, El lecho de Procusto, un libro de aforismos sobre ingenieros y economistas que me parece que pone un poco las cosas en su sitio.

- Tú eres profesor titular de Tecnología Educativa y Comunicación Audiovisual, ¿crees que ha mejorado la metodología docente en la universidad con la introducción de las llamadas «nuevas tecnologías»?

En 1999 participé en la Universidad de Cantabria en un plan de formación de profesores jóvenes y les introduje en el uso del Power Point, en un tiempo en el que los más arriesgados trabajaban con láminas de retroproyección. La experiencia fue fantástica porque, en el fondo, Power Point es una continuación digital de las láminas de retroproyección, integrando diversos recursos como imágenes, textos, animaciones, jerarquía de colores, etc. Pero hoy esas técnicas están agotadas; como muy bien explican autores como Nicholas Carr, son recursos previsibles 
que apenas aportan interés al alumnado en clase. Al mejor profesor que he visto usar Power Point, ha sido a Tom Peters, que usaba las pantallas a modo de señal o indicador para expresar y ampliar conceptos complejos que no aparecían en la proyección. Cuando un profesor lee lo que ponen las pantallas proyectadas, es evidente que no ha entendido nada de las potencialidades del recurso tecnológico, y es una práctica muy común. En mi caso, desde finales de los noventa más o menos elaboro mis contenidos con herramientas de autor, comencé con director, pero me parecía muy farragosa y había que aprender Lingo, un lenguaje propietario que necesitaba de una curva de aprendizaje muy alta. Un día descubrí Opus Creator de Digital Workshop con el que llevo trabajando desde finales de los noventa en sus diferentes versiones. Una aplicación que ahora enseño en las clases, y en apenas tres semanas de prácticas, el alumnado, con una creatividad desatada, prepara materiales curriculares digitales para sus prácticas en los colegios que hacen en pizarras o en los ordenadores y las tabletas android. Además, es una muy buena oportunidad que les proporciono para reflexionar sobre la forma en la que se estructuran contenidos integrados en el espacio digital. Estoy hace tiempo intentando crear un grupo de escritura digital para docentes, tengo incluso un curso en Moodle preparado, pero todavía no ha cuajado la idea, a pesar de que acabo de presentar un proyecto de innovación con técnicas interactivas con pdf que ha sido muy bien valorado. Es un campo que viene de mi anterior trayectoria como técnico que ahora, pasado por las reflexiones didácticas, me parece muy útil para los docentes. Yo lo uso en mis asignaturas, tanto las fichas interactivas en pdf, como los materiales didácticos con las herramientas de autor, y me funciona muy bien con los alumnos y en las conferencias que imparto.

\section{- Y el alumnado universitario también ha cambiado mucho...}

A mí los alumnos y alumnas actuales me encantan. Digan lo que digan de ellos son las generaciones mejor preparadas que han pasado por la universidad española. Es verdad que no leen mucho, y que eso se nota en la falta de capacidad de organizar el pensamiento y la expresión, pero adquieren conocimientos por otras vías diferentes, son muy hipervisuales, y algunos de nuestros métodos siguen estando en un tiempo que ya no es el suyo. Ya lo predijo Umberto Eco, nada menos que en 1964, en Apocalípticos e integrados, que nos encontraríamos con generaciones para las que la superficie de las cosas sería más importante que 
su esencia y reflexión. Navegamos todos en esta cultura posmoderna de superficie que ha borrado muchas de las referencias culturales que teníamos, y no es solo un fenómeno español sino internacional. En estos momentos, en la universidad española, quienes más en serio se toman sus estudios son las mujeres, tal vez porque cada vez son más conscientes de su techo de cristal. Educación está muy feminizada, y para mí es un lujo contribuir a que sean más críticas y conscientes de la complejidad de la cultura tecnológica de este tiempo. Tenemos unas clases de buenas prácticas con las TICs para dotarlas de un cierto liderazgo tecnológico en las aulas con sus alumnos y sus familias, y comenzamos con una sesión que yo título "perdiendo la inocencia punto com», en la que descubren la fragilidad de los facebook, los twiters, whatsapps, los correos y todo lo que constituye ahora sus formas de intercomunicación digital. Las digo que me dejen su teléfono cerrado y sin cables y en unos minutos las leo todos sus mensajes sin saber las contraseñas, o que con un software de cien euros las leo todas las capas borradas de su pendrive, que la digitalidad es muy poco segura. Al acabar la asignatura hacen una memoria de sus cambios de percepción tras su aprendizaje, y compruebo que lo que creían que era la típica asignatura de informática les ha abierto la mente, y están más preparadas para ser docentes en un entorno cada vez más complejo, pero que se explica muy bien desde la continuidad cultural de la tecnología, y ahí, de nuevo, entra la historia, que permite comprender porque estamos aquí y cómo hemos llegado hasta aquí con las prácticas tecnológicas actuales. La visión del proceso histórico me parece muy determinante para el alumnado.

- ¿Podríamos decir que el alumnado actual, a pesar de tener mucha más facilidad para acceder a una gran cantidad de información gracias a la tecnología digital, tiene más dificultades para gestionarla?

Mi sensación es que tienen habilidades digitales, aprendizajes realizados con sus amigos y amigas, pero carecen de una integración de los significados culturales de la digitalidad, y esa es una de mis tareas en el aula. Una de las patologías que tenemos ahora en la universidad se manifiesta muy bien el día que presentas la asignatura y alguien levanta la mano y pregunta «¿cómo va a ser el examen?». A lo que siempre contesto: «Ah, pero... ¿hay que examinaros? Primera noticia, ¡nadie me había dicho nada!». Cuando más extrañados están de mi respuesta les hablo de que hemos perdido la pasión por el viaje, que lo importante no es el 
examen sino aprender cosas nuevas que les sirvan para su mochila vital y profesional, y digan lo que digan de los alumnos actuales, cuando les cuentas cosas que les interesan, y encuentras el método para hacerlo, puedes aguantar clases de dos o tres horas sin que se aburran. Soy consciente de que hay materias como las mías que son más fáciles para hacer esto que otras, pero reitero la idea de que son muy visuales. Cuando estaba en Extremadura impartía en tercero de Comunicación Audiovisual una asignatura, Narrativa Audiovisual, que está tradicionalmente concebida como una taxonomía de los diferentes elementos que conformaban el texto audiovisual, y al segundo día me di cuenta de que iba a ser un curso muy duro. Así que me fui a un videoclub, saqué unas cuantas películas en dvd, y de cada etiqueta taxonómica hice un corte de vídeo que monté en mi herramienta de autor. La asignatura funcionó muy bien y aprendimos todos mucho, yo el primero. Se trata de una cuestión de adaptación de los métodos a las exigencias del conocimiento.

- Permitenos volver a tus inicios en la investigación histórica. Eres doctor en Historia Contemporánea (1998) con una tesis dirigida por Ángeles Barrio bajo el título "Funciones de las imágenes durante el reinado de Isabel II», en la que trabajaste con grabados y fotografías, analizando las influencias de ambas técnicas y sus usos sociales y culturales ¿Puedes hablarnos de esta investigación?

Ángeles Barrio fue siempre muy generosa conmigo, y a la vez me enseñó a investigar y me dio mucha libertad de actuación. Ángeles es una reconocida experta en la historia del anarquismo y del movimiento obrero en la primera Restauración. Me había dirigido la tesina, y yo la pedí que me dirigiera la tesis en la que, sobre el fondo de la evolución el sistema informativo liberal en el siglo XIX, me interesaba estudiar dos aspectos fundamentales en torno a las imágenes. En primer lugar, el nacimiento de la información gráfica que no ocurrió con la fotografía, sino con el grabado en madera en las revistas ilustradas, y de ese análisis, intentar, en segundo lugar, demostrar que las imágenes están dotadas de discursos históricos que es posible analizar e integrar en el texto historiográfico. Por eso el trabajo tiene varias vertientes: una historia de la prensa gráfica y de la cultura que la hace posible en el siglo XIX en España sin perder la perspectiva internacional; una comprensión del lector/espectador que consume esas imágenes y cómo las entiende, para abordar con ello el problema de los tiempos en las propias representaciones, es decir, un 
historiador actual no puede entender las fotografías o los grabados del mismo modo que las recepcionaba un lector/espectador del tiempo en que se produjeron porque los valores culturales en torno a las imágenes han cambiado y hay que tenerlo en cuenta en el análisis histórico; y un estudio de las tecnologías del grabado y de la fotografía con sus posibilidades y limitaciones discursivas. Tuve el lujo de ver miles de páginas de prensa del XIX porque todavía podías trabajar sobre los originales que no estaban digitalizados. Fui seleccionando imágenes en microfilm que luego convertí a imagen digital, almacené imágenes en la entonces nueva tecnología del Photo CD de Kodak, y el resultado fue un trabajo muy inédito sobre las posibilidades documentales de las imágenes en el tiempo que nació la cultura de la información gráfica en la prensa, y una reflexión que pretendía ser una guía de trabajo para otros historiadores. El libro resultante está abierto en Google Books, digitalizado de un ejemplar de una universidad americana y ha sido muy consultado en todo momento. Cerré el trabajo con las primeras experiencias de fotograbado en la España con motivo del terremoto de Andalucía en la Navidad de 1884, y ese es el punto donde arranca la investigación que estoy haciendo ahora sobre el espectador de la sociedad de las masas que consume imágenes impresas en las revistas o magazines desde comienzos del siglo XX, va a las barracas de cinematógrafo, asiste al auge de la tarjeta postal y con todo ello se va configurando una nueva cultura de los media en detrimento de la alta cultura; un aspecto que esbocé en los coloquios de Historia de la Educación y en el texto que he escrito sobre la conferencia que impartí.

- La historia se ha construido tradicionalmente con lo que tú mismo a veces has llamado "materiales más nobles». Háblanos de la problemática de usar otros materiales para la investigación histórica como los grabados, las fotos... ¿Tuviste muchas dificultades metodológicas para aplicar el análisis histórico a las imágenes?

Cuando comencé a investigar no había nada escrito sobre esta temática. A mí me fue muy útil al comienzo toda la línea iconográfica de Ernst Gombrich como punto de referencia, pero lo que sí había era un movimiento de recuperación cultural de la fotografía histórica española que había comenzado en 1981 del que formo parte desde los orígenes. Autores procedentes en su mayoría del medio fotográfico habíamos comenzado a trabajar sobre fotógrafos del pasado con una metodología 
que se conocía como Fotohistoria. En mi caso publiqué en 1987 un libro en Lunwerg que se tituló Cien Años de Fotografía en Cantabria en el que colaboró un fotógrafo local, Ángel de la Hoz, y que fue un gran éxito. Pero a mí la metodología me dejó muy insatisfecho porque, como escribí en un momento determinado, «estábamos haciendo historia de la fotografía, pero no Historia con la fotografía». En 1990, en la ciudad de Girona, comenzaron las jornadas Antoni Varés de investigación histórica de la fotografía, organizadas por Joan Boadas, responsable de archivos del ayuntamiento de la ciudad de Girona. Ese fue mi verdadero laboratorio de ideas donde fui avanzando algunas de las cuestiones que luego plasmé en mi investigación. En aquellos años, aunque estaba ya muy desgastada su epistemología, el análisis de las imágenes estaba colonizado por la semiótica estructural a la que yo había seguido atentamente comprando libros en París sobre esta temática, y pronto descubrí que el tiempo semiótico y el tiempo histórico tenían muy difícil concordancia. A la vez indagué sobre la escuela fotohistórica que habíamos recepcionado en la tarea de poner en valor las imágenes fotográficas españolas, y descubrí que provenía de un movimiento que un coleccionista llamado Beaumont Newhall había puesto en marcha en 1937 a partir de una exposición en el MOMA de Nueva York asimilando conceptos de la historia del arte, pero que a las alturas en las que estábamos era ya muy insuficiente. En 1994 Carmelo Vega, un profesor de Historia del Arte de la Universidad de la Laguna que provenía como yo del movimiento de recuperación cultural de la fotografía, publicamos un librito titulado Fotografía y métodos históricos, dos textos para un debate, que puso de manifiesto que las bases sobre la que estábamos trabajando eran ajenas a la comunidad universitaria a la que no le interesaban esos planteamientos historiográficos. Carmelo Vega y yo hemos trabajado en paralelo sobre estas cuestiones, en mi caso en la revista Ayer y en varias publicaciones a lo largo del tiempo, y él, además de otros trabajos, acaba de publicar un libro esplendido sobre Historia de la Fotografía en España que tuve el privilegio de presentar a finales de 2017 en la librería del Centro Reina Sofía.

Hay una cuestión que recuerdo sobre los inicios de la denominada Fotohistoria en España y de la que he hablado en un texto que publiqué con motivo de los veinte años de las Jornadas Antoni Varés. Tuvimos un encuentro en Sevilla en 1986, donde nos conocimos quienes de manera 
aislada habíamos comenzado en nuestras localidades a recuperar cultura fotográfica. Muchos seguimos siendo amigos, y cuando nos vemos recordamos aquellos años en los que comenzaba a darse una patrimonialización de los fotógrafos que íbamos descubriendo. Si yo había descubierto la obra de, pongamos, Zenón Quintana, un autor del siglo XIX muy importante en Santander, era «mi» fotógrafo, y nadie más que yo podía hablar de él. Por otro lado, había la obsesión de subir al panteón internacional nombres españoles que así se revalorizarían en el mercado del coleccionismo, y yo estuve en una absurda reunión con uno de los historiadores franceses de la fotografía del momento que quería que yo fuera una especie de agente pro-francés en mis estudios sobre fotografía para frenar la influencia anglosajona que se estaba dando en la revalorización de autores como Charles Clifford. Todo era un disparate. En Sevilla comprendí que, si no ensanchábamos la base de interés de nuestro trabajo, seríamos irrelevantes en muy poco tiempo. Hoy los estudios de historia de la fotografía los sustentamos un pequeño pero sólido grupo universitario que hemos encontrado nuestro lugar en el ámbito académico, y nuestro trabajo es apreciado y es una especialidad más, que es lo verdaderamente relevante.

- ¿Qué aceptación tuvo en ese momento, dentro de la comunidad científica de historiadores contemporáneos, tu forma de analizar las imágenes y sus significados sociales?

Claro, yo jugaba con una cierta ventaja. Por un lado, personas como mi directora Ángeles Barrio eran para mí un termómetro del interés que despertaba mi esfuerzo de hacer de las imágenes documentos históricos. Había dos cuestiones evidentes. Cuando enseñabas fotografías del pasado a un historiador profesional se interesaba mucho por lo que mostraban, pero te dabas cuenta enseguida de que carecía de estrategias de análisis más allá de la evidencia de lo que representaba la imagen. El nivel de trabajo con una fotografía era para ilustrar un hecho sin detenerse en los aspectos discursivos que podía presentar la imagen, algo que, sin embargo, cualquiera estaba muy bien entrenado con los textos escritos. En el departamento de Historia Contemporánea de la Universidad de Cantabria me gané el respeto de todos porque veían que mi trabajo intentaba ser muy serio, hablaba su mismo lenguaje y entendía la imagen como un elemento más del material documental histórico. No había descubierto la pólvora, sino que tan solo estaba incorporando 
otras aproximaciones. Publiqué mucho, y en muchos sitios en aquellos años, textos que siguen usándose como referencia, como la cuestión de los viajes de Isabel II tras la crisis del bienio progresista a partir de unos álbumes fotográficos magníficos que se conservan en el Palacio Real de Madrid a los que doté de sentido político e historiográfico; o la operación de construcción de la imagen de Alfonso XII, de niño desvalido que había perdido injustamente su corona a rey pacificador en 1876. Las imágenes utilizadas en su época operaban como un documento más en el texto historiográfico, y mis colegas veían que lo que yo publicaba era pertinente. Fue muy decisivo para mí también participar en los seminarios que organizaron en 1995 Antonio Rodríguez de las Heras en la Universidad Carlos III de Madrid con Carlos Serrano, catedrático de la Sorbona, en la que nos juntamos diversos historiadores españoles y franceses y trabajamos sobre aspectos históricos de las imágenes. Fue tal vez el primer momento en que sentí que mi trabajo no era tan solitario. De aquella época conservo muy buenos amigos: hace muy poco he estado en París con Marie Linda Ortega, una discípula de Carlos Serrano, especialista en los grabadores madrileños del siglo XIX, y de aquel grupo han salido historiadores más jóvenes como Antonio Pantoja o Beatriz de las Heras que continúan haciendo de las imágenes su material documental.

- Como bien sabes, el debate sobre el uso de la fotografía como fuente, su forma de interpretarla e incluso su posible utilidad en la investigación histórica ha estado presente entre la comunidad científica de historiadores de la educación en España durante la última década, ¿qué percepción tienes de cómo se ha desarrollado esta línea de investigación?, ¿en qué aspectos confluye y en cuáles se distancia nuestra investigación histórico-educativa con la que habéis desarrollado los historiadores de la imagen y de la fotografía?

El encuentro en la Universidad de las Islas Baleares y el posterior monográfico fueron para mí un encuentro muy revelador y prometedor. Me encontré con un grupo de historiadores de la educación que estaban aproximándose a las imágenes fotográficas, que no necesitaban saber si una fotografía era una albúmina, o un gelatino bromuro, pero que analizaban lo que estaba en la representación y lo ponían en valor con sus indagaciones sobre la renovación pedagógica. Me quedé fascinado porque coincidía con mi convicción de que, para usar las imágenes como fuentes documentales, además de tener un poco de 
metodología específica, lo importante era el contexto de la representación, su cadena institucional y los elementos discusivos que intentaban mostrar. El monográfico de Educació i Historia fue magnífico. Ya en la propia presentación de Francesca Comas se ponía el énfasis en la fotografía como un nuevo material historiográfico, y la necesidad de diversificación temática para conocer el pasado educativo. Los autores que participamos cumplimos muy bien el objetivo de dar una visión múltiple de la cuestión de las imágenes en el ámbito educativo, y creo que fue uno de esos trabajos seminales que marcó una línea ascendente a partir de 2010 que, en mi caso, pude comprobar la evolución positiva en el coloquio de historia de la educación de San Lorenzo del Escorial en septiembre de 2017. A mí la experiencia de las Islas Baleares, me reveló que, en un ámbito especializado como la historia de la educación, el análisis de las imágenes iba a tener un desarrollo muy extraordinario como así ha ocurrido. Yo en estos momentos me siento uno más de los historiadores de la educación. Estoy leyendo todo lo que puedo, me encantan y me iluminan los trabajos tan prolíficos de Antonio Viñao, como el de la enseñanza de la lectura que he descubierto ahora, y las exposiciones sobre imágenes postales escolares comisariada por Antonio Viñao junto a María José Martínez y Pedro Luis Moreno, y la reciente de cuadernos ilustrados que están haciendo en la Universidad de Murcia. Siento un gran afecto a María del Mar del Pozo Andrés y siempre me sorprende su enorme capacidad de trabajo. En el coloquio de San Lorenzo del Escorial me sentí muy a gusto con todas las personas que conocí, y algunas como Bernat Sureda o Teresa Rabazas que ya había conocido en Palma de Mallorca, y por supuesto a Francesca Comas. No quisiera hacer un listado de nombres para quedar bien, solo decir que me parece un grupo de muy alto nivel y me siento muy a gusto colaborando en todo lo que pueda y sepa.

- ¿Cómo puede ayudarnos, a nivel metodológico, el análisis de ciertos géneros fotográficos en la investigación histórico-educativa? Para poner un ejemplo concreto, ¿qué crees que se podría aportar, desde el estudio del retrato como género, al análisis del retrato de recuerdo escolar?

El género del retrato es un material extraordinario en general, porque de las rutinas de la representación se pueden extraer informaciones y valores culturales y sociales muy interesantes que rozan la antropología 
cultural. El retrato es un encuentro de la sociedad con la tecnología fotográfica, y en el siglo XIX es claramente un acto de afirmación de la modernidad de la fotografía en un espacio teatralizado, hasta el punto de que los trajes que distinguen a los retratados de la forma de vestir de la sociedad tradicional son aportados por el propio fotógrafo. Antonio Flores hizo una magnífica disección de esta práctica en 1863 en su «retratos en tarjeta», y en 1984, Jean Sagne estudió en L'Atelier du photographe, 1840-1940, muchos matices de una cultura de representación que es inherente a la propia práctica de la fotografía. Estoy de acuerdo con que la fotografía escolar es una mirada externa a la institución, y muy estereotipada, pero esa característica la hace muy interesante porque proyecta sobre la escuela valores sociales externos y vigentes culturalmente. Y admite muchas variantes de representación como nos mostró Francesca Comas en el coloquio de San Lorenzo del Escorial en un trabajo muy interesante. En mi casa conservamos una foto escolar de mi esposa cuando era niña, que, en este caso, el fotógrafo ponía a las alumnas de la escuela del pueblo encima de su moto Lambretta como un signo de modernidad obviando los objetos escolares, pero los mapas, los libros y todos los cachivaches educativos daban idea de una visión de la escuela que se cruzaba con la memoria personal y la educativa de la sociedad. Hace unos meses los alumnos de la Facultad de Educación me eligieron como uno de los profesores que tenía que salir en la orla, porque aquí eso se vota y no salen todos, algo que ignoraba. Total, que fui al estudio del fotógrafo y me sorprendió reconocer de nuevo toda la industria del simulacro que tenía allí, entre un triciclo y un balón de colores había una falsa camisa y corbata, un remedo de traje académico con los colores de cada doctorado y todo ello daba una impresión de realidad que en su materialidad no tenía. Pensé entonces que una parte de nuestra cultura visual está formada de apariencias que vienen de las prácticas del estudio en el siglo XIX, pasan por el cinematógrafo donde todo en la escena es mentira, y sigue hasta nuestra cultura posmoderna que tan acertadamente intuyó en su momento Jean Braudillard y ahora se agudiza con la ficción que producen las tecnologías de postproducción digital. Las fotografías escolares se insertan en esa tradición del simulacro que se ha instalado en nuestra cultura. Es más, yo creo que es uno de los elementos de identidad de esa tradición, porque la escuela es una experiencia vivida por todos y su memoria fotográfica intenta resumir esa experiencia con imágenes que, como bien apuntas, en muchos casos 
no representan a lo verdaderamente esencial de lo que ha sido la vida escolar.

- La investigación histórico-educativa con fotografías nos ha llevado también a reivindicar su necesidad de conservación como parte de nuestro patrimonio. Esto nos hace pensar que las fotografías actuales también deberían preservarse. Hoy en dia, sin embargo, aunque tengamos muchos más medios para fotografiar el presente, su conservación e incluso su utilidad futura como fuente histórica ya ha sido tema de debate. ¿La fotografía digital puede presentar problemas para su preservación?

Afortunadamente hay una sensibilidad patrimonial en torno a la fotografía que ha alcanzado también a nuestro país. Desde el movimiento de su puesta en valor a partir de 1981, las colecciones públicas están catalogadas y conservadas y en Girona cada dos años, gracias a las Jornadas Antoni Varés, hay un encuentro de conservadores y archiveros al que nos sumamos historiadores y otros expertos; tiene hace muchos años una dimensión internacional y las problemáticas que tenemos entre nosotros son similares a las de otros países. La materialidad del documento fotográfico es muy compleja porque es un producto de la química y además de orígenes muy diversos, sobre todo en el siglo XIX. En este sentido, tenemos buenos especialistas en conservación e intervención en casos de materiales dañados por diversas causas. La sensibilidad de que son documentos esenciales de la contemporaneidad está bastante instalada en la sociedad y, sin ser triunfalista, se ha hecho el trabajo correcto en estas décadas. A nivel europeo existe una iniciativa de conservar y difundir las colecciones fotográficas europeas y la digitalidad ayuda porque, por un lado, preserva documentos que en algunos casos son muy frágiles, los hace accesibles a muchas personas, y algo muy importante, rompe esa tradición patrimonial de los archivos que piensan que lo que conservan es suyo y no de la sociedad. Yo estoy muy a favor de la imagen digital, que paradójicamente presenta otros problemas de conservación específicos, pero que permite la difusión como nunca ha sido posible hasta ahora. Como generación tenemos la obligación de conservar y transmitir al futuro esos objetos visuales de nuestra cultura, y para una gran parte de los análisis que hacemos el encuentro con el objeto real no es tan necesario si la digitalización es correcta, y el que la ha hecho ha tenido en cuenta preservar toda la información del objeto, no solo la imagen que representa. 
Otro problema es cuánto de las imágenes de nuestro tiempo se va a conservar, si tenemos en cuenta que plataformas como Instagram publican al día en estos momentos ochenta millones de fotografía, una cantidad que ya no está al alcance de los humanos, y solo las máquinas tendrán capacidad de ver ese número ingente de imágenes en el futuro. La digitalización plantea incertidumbres evidentes, pero era obvio que no había ya materia prima suficiente de sales de plata para mantener el consumo ascendente de las imágenes fotoquímicas. Pero, en resumen, yo creo que la sensibilidad de preservación está bien instalada en la cultura social.

\section{- ¿Y para su interpretación histórica?}

Por cuestión generacional he sido un historiador que ha manejado los objetos originales en sus investigaciones, lo mismo periódicos, libros o imágenes fotográficas, pero me consta que los historiadores más jóvenes se encuentran cómodos con los periódicos digitalizados o con las imágenes en ese soporte. En muchos casos no necesitamos estresar al original para extraerle sus contenidos, y existe hasta un cierto, diríamos, fetichismo en ello que creo innecesario. En otras ocasiones sí es necesario trabajar con los originales. Un ejemplo, los problemas que tiene Charles Clifford con las escenas urbanas de los viajes de Isabel II, la poca sensibilidad de las placas y cómo resuelve magistralmente los fantasmas que le aparecen en las tomas con motivo de los objetos en movimiento, solo pueden apreciarse con precisión si accedes a las grandes imágenes fotoquímicas en albúmina que están en los álbumes. Pero ese es un nivel de análisis muy concreto que no siempre es necesario. Si lo que necesitas estudiar es precisamente el urbanismo de las ciudades a mediados del XIX a través de estas fotos, una buena reproducción digital te lo permite. Yo creo que tiene que haber un equilibrio entre preservación e investigación. Y ese equilibrio no debe ser solo de los conservadores de los fondos, sino también de los historiadores. Asimismo, defiendo que la sociedad tiene derecho a contemplar en ocasiones las piezas originales siempre que se den las condiciones de seguridad adecuadas, porque nosotros no somos propietarios de esas imágenes, sino solo conservadores temporales hasta que lleguen las próximas generaciones que tienen el mismo derecho que nosotros, y eso tenemos que entenderlo aunque haya personas a las que les cueste. 
- El nivel de interpretación de la fotografía histórica alcanzado hasta ahora (modelos de análisis, categorías, iconografía, etc.), ¿tendrá valor para los historiadores del futuro que se enfrenten a la fotografía actual como fuente? ¿Puedes aportarnos algunas reflexiones al respecto?

Pienso que la historia del conocimiento es acumulativa y dinámica. En el sentido de que los trabajos y hallazgos de diversos autores permanecen, pero pueden caer en desuso y aparecer otras premisas nuevas. Como muy bien decía Machado "lo nuestro es pasar, pasar haciendo camino", y como historiadores sabemos muy bien que cuestiones que parecían muy importantes en un momento dado, luego se olvidan y aparecen otras que las reemplazan. Es el ritmo normal del conocimiento y así debemos asumirlo. Las fotografías no son sino una parte de un complejo cultural más extenso de la contemporaneidad que es la representación de lo real con imágenes de acuerdo con unas condiciones ideológicas de fidelidad especular que antes de la invención de la fotografía en 1839 no estaban presentes ni formuladas. El trabajo histórico que hemos hecho muchas personas en todo el mundo es poner en valor unas fuentes visuales que no se pueden obviar para entender el mundo moderno que nace con la Ilustración a mediados del siglo XVIII y se desarrolla a lo largo del siglo XIX y del XX, y sigue en el XXI con la digitalidad. Un mundo ya de largo recorrido en el que nacen otras tecnologías que también captan la realidad. Nosotros nos hemos educado en una concepción de tecnologías separadas con significados por lo tanto diferentes. Pero, por ejemplo, Andrea Cuarterolo, en su De la foto al fotograma, relaciones entre cine y fotografía en Argentina (1840-1933), publicado en 2013, se atrevió a abordar el estudio de la historia de Argentina mezclando fotografía y cine, y el resultado fue espectacular. Creo que hay mucho camino por recorrer y que lo que hemos logrado es llamar la atención sobre la importancia cultural de la fotografía en las sociedades de las que formamos parte. A mí lo que me preocupa es la continuidad de nuestros trabajos, porque hubo una época que parecía que la historia de la fotografía tenía mucho más auge, pero creo que es un documento tan importante y esencial que ese interés persistirá, tal vez no con algunas de las premisas que ahora defendemos, pero la senda está ya marcada. Por eso una de mis obsesiones es la difusión de los trabajos de historia de la fotografía, y ese es el sentido de mi blog (bernardoriego. wordpress.com) que intenta explicar el origen de mis textos publicados 
y poner en valor a los que formamos parte de esta pequeña comunidad de historiadores de la fotografía que seguimos en la brecha, y las incorporaciones sectoriales como la que se ha producido con los historiadores de la educación, que es tan fructífera, es una muy buena noticia. Creo que no hay que ser pesimistas en ningún caso.

- Más allá de la historia de la imagen, una de sus líneas de trabajo académico e investigador se centra en los cambios que está produciendo en la sociedad y en los ámbitos económicos y culturales las Nuevas Tecnologías de la Información y el Conocimiento propiciadas por la revolución digital. ¿Puedes hablarnos sobre esta línea de trabajo?

Un autor que me marcó mucho en su momento fue Lewis Mumford. Con su trabajo entendí que la tecnología no estaba en la parte de atrás de los fenómenos, sino que era esencial, y partiendo de esa convicción me ha interesado mucho la tecnología como una parte que estudia la sociedad y le da sentido y explicación. Me ocurre una cosa en estos momentos muy curiosa, y es que me siento ya un arqueólogo de técnicas que han quedado en desuso pero que generacionalmente pude conocer. Hace dos años descubrí en la Biblioteca de Cataluña un libro de un grabador gallego que explicaba a comienzos del siglo XX las prácticas del fotograbado que yo he conocido de primera mano, y siento que a los que en el futuro expliquen el fotograbado les ocurrirá lo mismo que me ocurre a mí cuando quiero entender un espectáculo de linterna mágica, que no lo he conocido y lo reconstruyo desde la racionalidad. Por eso estoy pensando en hacer un blog de arqueología tecnológica para dejar algo de memoria y emoción personal sobre técnicas que fueron muy relevantes y que están ya obsoletas. Por ejemplo, la edición de vídeo analógico. Tenemos una exposición en la Facultad de Educación de la Universidad de Cantabria titulada «recuperando utopías» que habla precisamente de la utopía educativa de que con las máquinas se enseña y se aprende mejor. Se trata de aparatos tecnológicos que hemos usado a lo largo del tiempo, y lo que más me sorprende, y me inquieta, es que todas las máquinas que están expuestas, además de en desuso y obsoletas están vivas y se pueden utilizar, pero social, tecnológica y culturalmente están muertas, aunque sus funciones sigan activas. Cuando montamos la exposición tuve buen cuidado de preservar los cables y los elementos que las harían funcionar en el futuro si alguien estuviera interesado en ello. Vamos tan acelerados que, a diferencia de otras épocas 
históricas, las máquinas se sustituyen antes de que acabe su ciclo funcional; este es otro de los muchos fenómenos nuevos a los que asistimos en estos tiempos.

Me interesa mucho como historiador y educador el nuevo tiempo que ha emergido con la Sociedad de la Información. Ya he contado antes que he tenido el privilegio de conocerlo en la triple vertiente de usuario, docente y gestor y además tengo la suerte de impartir docencia sobre tecnología digital a los nuevos alumnos y sobre historia de la sociedad de la información a generaciones del programa Senior que, como yo, asistieron a la implantación de esas tecnologías a partir de la década de los años ochenta y en algunos casos antes por las máquinas corporativas que se instalaron en algunas empresas. Hay cuestiones que me interesan mucho. Una es postularme contra el adanismo, típico de la industria digital que presume de que antes de ellos no había nada parecido, pero no es así. Por ejemplo, la conmutación de paquetes, que hace posible que funcionen los correos electrónicos por redundancia de mensajes, ya se probó con palomas mensajeras en la Guerra Franco-Prusiana en 1870-71; el principio era el mismo, aunque es evidente que las tecnologías eran diferentes. Otra cuestión que me interesa mucho es la aceleración tecnológica que en lugar de fascinarnos con las novedades, tiene que hacer que nos centremos en lo esencial, y en mi opinión, lo esencial es que se ha producido un enorme salto en pensamiento simbólico sin precedentes con la virtualidad de los objetos digitales que todos manejamos cada día; que es cierto también que estamos enseñando a maestros y maestras que no conocen algunas las profesiones a las que se dedicarán en el futuro su alumnado; y que la tecnología en sí misma es una parte ineludible de nuestra cultura. Eso intento transmitir en mis clases, ayudando a que los futuros docentes sean críticos y reflexivos y que al mismo tiempo no rechacen ni fantaseen con su tiempo, sino que intenten comprenderlo.

Creo que la cultura y la educación son dos herramientas maravillosas para el desarrollo de las sociedades y de las personas, y me gusta ser muy flexible y abierto. En un seminario que impartió Tom Peters al que asistí, comentaba que deseaba que en su tumba pusieran el siguiente epitafio «I was only a player». Yo tengo otra frase mágica que no es para la muerte sino para la vida: «Invierte siempre en aquello que un naufragio no te pueda arrebatar». 
- Gracias, Bernardo, por compartir con nosotros estas reflexiones.

Muchas gracias por la oportunidad que me habéis brindado de darme a conocer un poco y recordar algunas cosas de mi trayectoria. Ha sido un verdadero placer.

\section{OBRAS DE BERNARDO RIEGO AMÉZAGA}

\section{Libros}

- Loterías y Apuestas del Estado. 250 Años de Historia. (Barcelona: Lunwerg, 2015).

- España ayer y hoy (Barcelona: Lunwerg, 2012).

- (editor y autor) España en la tarjeta postal, un siglo de imágenes (Lunwerg, 2010).

- Impresiones. La Fotografía en la Cultura del Siglo XIX. (Girona: CRDI, 2003).

- La construcción social de la realidad a través de la fotografía y el grabado informativo en la España del siglo XIX (Cantabria: Universidad de Cantabria, 2001).

- Memorias de la mirada: las imágenes como fenómeno cultural en la España contemporánea: del 11 de octubre al 25 de noviembre de 2001 (Fundación Marcelino Botín, 2001).

- La introducción de la fotografía en España: un reto científico y cultural (Girona: CRDI, 2000).

- (Con Ángel Fuentes e Isabel Arguerich) Manual para el uso de archivos fotográficos (Santander/Madrid: Universidad de Cantabria y Dirección General del Libro, Archivos y Bibliotecas del Ministerio de Educación y Cultura, 1997).

- Instantes de la Memoria. Torrelavega en sus Fotografías (1878-1960) (Torrelavega (Cantabria): Ayuntamiento de Torrelavega, 1996).

- (Con Carmelo Vega) Fotografía y métodos históricos: Dos textos para un debate (Santander/Santa Cruz de Tenerife: UC y Universidad de la Laguna, 1994).

- El espejo constante. Memoria Fotográfica de Santander y su puerto (18611950) (Autoridad Portuaria Santander. Colección Navalia, 1994).

- (con Luís Carandell) Telefonía: la gran evolución (Lunwerg, 1992).

- (con Marie-Loup Sougez, Miguel Ángel Sánchez Gómez) La fotografía y sus posibilidades documentales: una introducción a su utilización en las ciencias sociales (Cantabria: Universidad de Cantabria, 1989).

- Cien años de Fotografía en Cantabria (Barcelona: Lunwerg, 1987). 


\section{Participación en obras colectivas}

- «La exhibición de fotografías y el diálogo con el espectador», en Patrimonio fotográfico: de la visibilidad a la gestión, coord. Antonia Salvador Benítez (Gijón: Ediciones Trea S.L. 2015), 185-216.

- "Contemplando las postales en su contexto narrativo: Influencias y Referencias Culturales», en Correspondencia sin Privacidad. Billetes, Tarjetas Postales y Epístolas Literarias en la Colección Lázaro (Madrid, Fundación Lázaro Galdiano. 2013), 67-73.

— «Sombras o Reflejos: el misterioso poder de las imágenes más allá de sus tecnologías», en Un art d'espectres. Màgia i esoterisme en el cinema dels primers temps (Girona, Ed. Museu del Cinema - Universitat de Girona. Girona 2010), 85-102.

- «La fotografía, el cine y los fenómenos de borde en los inicios de la sociedad de las masas: una reflexión comparativa», en El fotógrafo como testigo de la historia, coord. Beatriz de las Heras Herrero (Madrid: Ocho y medio 2014), 15-36.

- «Un instrumento científico a la búsqueda de su identidad social», en Fotociència, coord. María José Mulet Gutiérrez, Miquel Seguí Aznar (Palma de Mallorca: Universitat de les Illes Balears 2009), 203-218.

- «La representación en las imágenes fotográficas. Discursos y Divergencias de cada tiempo histórico", en Fotografía e Historia. III Encuentro en Castilla-La Mancha (Ciudad Real: Ed. Centro de Estudios de Castilla-La Mancha. Universidad de Castilla-La Mancha, 2009), 67-87.

- «Un Tiempo de Generación: 10 ediciones de Jornadas Imatge i Recerca», en Imatge i Recerca, 10as Jornadas Antoni Varés (Girona, 2008), 11-21.

- «Miradas encontradas procedentes de una exposición», en Viaje de Ida y Vuelta. Fotografías de Castilla-La Mancha en The Hispanic Society of America (Toledo, Ed. Empresa Pública D. Quijote de la Mancha S.A. 2007), 18-23.

- «Algunos apuntes para construir una futura industria cultural digital», en Actas de los XVII Cursos Monográficos sobre el Patrimonio Histórico (Santander: Ed. Servicio de Publicaciones de la Universidad de Cantabria, 2007), 351-357.

- "Mirando las fotografías desde su entorno: la llave del imaginario», en El análisis de la imagen fotográfica, eds. Rafael López Lita, Javier Marzal Felici, Fco. Javier Gómez Tarín (Castellón: Publicaciones de la Universidad Jaume I, 2005), 19-32.

— «El espejo sin distancias: la fotografía de viajes entre la imprenta y el cine primitivo», en Imatge $i$ Viatge. De les vistes òptiques al cinema: la configuració de l'imaginari turístic (Girona: Ed. Fundació Museo del Cinema, 2004), 49-53. 
- «Visibilidades diferenciadas: usos sociales de las imágenes en la España Isabelina», en Ojos que ven, ojos que leen: textos e imágenes en la España isabelina, coord. Marie Linda Ortega (Madrid: Visor, 2004), 57-76.

- «La primera transición de soportes en la tecnología fotográfica y sus consecuencias sociales», en De París a Cádiz. Calotipía y colodión (Barcelona: Museu Nacional d'Art de Catalunya, 2004), 92-96.

- "Incisiones o impresiones: algunas relaciones entre el grabado y la fotografía», en Girona, primeres mirades (Girona: Ajuntament de Girona, 2003), 9-13.

- «La socialización de un nuevo imaginario: incógnitas, rupturas y continuidades. en Actas del Simposio: Arte gráfico y nuevas tecnologías. Organizado por la Fundación BBVA, la Calcografía Nacional y la Real Academia de Bellas Artes de San Fernando (Madrid, 2003), 139-159.

- "Visiones de un tiempo en transformación: el grabado informativo y su importancia cultural en la mentalidad del siglo XIX", en Estudios Históricos VI, Actas del Symposium «El grabado en el mundo digital». Ed. Diputación Foral de Guipuzcoa. Museo Zumalakarregi (San Sebastián, 2003), 111-127.

- «Obras Públicas y Progreso en el siglo XIX: La visión fotográfica», en Sagasta Ingeniero. Ed. Colegio de Ingenieros de Caminos, Canales y Puertos. Col. Ciencias, Humanidades e Ingeniería (Madrid, 2002), 147-169.

- «Chema Madoz: los laberintos de la objetividad”, en Encontros da Imagem, Braga (Portugal), 2002.

— «De la "Escuela Newhall” a las "Historias" de la Fotografía: Experiencias y propuestas de Futuro», en Fotografía. Crisis de Historia, ed. Joan Foncuberta (Barcelona: Ed. Actar 2002), 42-57.

- «La campaña de África de 1859, la primera guerra mediática española», en Comunicación, historia y sociedad: homenaje a Alfonso Braojos, coords. María Parias Sáinz de Rozas, Eloy Arias Castañón, María José Ruiz, María Elena Barroso Villar (Sevilla: Universidad de Sevilla, 2001), 563-576.

- "La "invención del futuro" en sus orígenes contemporáneos», en Humanismo y nuevas tecnologías en la sociedad de la información, coord. Julián Chaves Palacios (Badajoz: Universidad de Extremadura, Facultad de Biblioteconomía y Documentación, 2001), 11-38.

- «El documento fílmico y sus interrogantes para el historiador», en Imatge $i$ Recerca, 6as Jornadas Antoni Varés (Girona, 2000), 103-125.

- «Técnicas de Fotografía Digital», en Escuela y Sociedad Un Compromiso, ed. Consejería de Educación y Juventud del Gobierno de Cantabria (Santander, 2000), 124-129.

- «Fotografía de creación, crítica y mercado cultural: una necesaria adaptación a las nuevas realidades», en 7 fotógrafos españoles contemporáneos, 
Exposición organizada por la Agencia Española de Cooperación Internacional en Perú, Paraguay, Uruguay y Chile (Madrid 2000).

- «Las imágenes como fenómeno de opinión pública en la primera etapa de la Restauración», en La cultura española en la Restauración, ed. Manuel Suárez Cortina (Santander: Sociedad Menéndez Pelayo, Universidad de Cantabria, 1999), 193-220.

— «El Imaginario Fotográfico y sus Funciones sociales: De la Imagen Química a la Imagen Digital», en La Imatge i la Recerca Històrica, $5^{a}$ s Jornadas Antoni Varés (Girona, 1998), 69-94.

- «La tarjeta postal, entre la comunicación interpersonal y la mirada universal», en Santander en la tarjeta postal ilustrada (Santander: Ed. Fundación Marcelino Botín. Col. Historia y Documentos. 1997), 19-57.

— «Del "Museo" enciclopédico a la información gráfica: el grabado en madera y sus funciones en la prensa ilustrada nacional», en: Libro homenaje a José Altabella (Madrid: Ed. Universidad Complutense de Madrid. Facultad de Ciencias de la Información, 1997), 235-251.

- «El Documento fotográfico y sus significaciones temporales», en Actas del $5^{\circ}$ Congreso de Historia de la Fotografía (Buenos Aires, 1996), 163-173.

- «La Mirada Fotográfica en el Tiempo: Una Propuesta para su interpretación Histórica», en Las Edades de la Mirada, ed. Mario P. Díaz Barrado (Cáceres: Universidad de Extremadura, 1996), 215-236.

- «Apariencia y realidad: El documento fotográfico ante el tiempo histórico», en La Imatge i la Recerca Històrica, 4ª s Jornadas Antoni Varés (Girona, 1996), 188-202.

- «El Fotomatón: La Fotografía Sin Autor», en Memoria del $3^{\circ}$ Congreso de Historia de la Fotografía en La Argentina (Buenos Aires, 1995), 55-58.

- «La imagen como un mapa de significados: El caso del estudio, un espacio para la representación social», en La Imatge i la Recerca Històrica, $3^{a}$ s Jornadas Antoni Varés (Girona, 1994), 217-233.

- «Luis de Ocharan's Photographic "Quixote”: Between the Spanish Historical Pictorial Tradition and the New Cinematographic Aesthetic», en Photography 1900 (Edinburgh: National Museums of Scotland and National Galleries of Scotland, 1994), 69-73

- «La Fotografía en la Enseñanza Universitaria: Hacia un Futuro sin Apenas Pasado», en Jornadas de Estudio Nueva Lente. Inicio y Desarrollo de la Fotografía de Creación en España, organizadas por la Consejería de Educación y Cultura de la Comunidad de Madrid, Canal de Isabel II (Madrid, 1993), 203214.

- «Una multitud de procesos denominados: Fotografía», en La Imatge i la Recerca Històrica, $2^{a}$ s Jornadas Antoni Varés (Girona, 1992), 67-87. 


\section{Artículos}

- «Las nuevas prácticas culturales con las imágenes digitales y el recorrido de su arqueología histórica», Leña al Mono 5-6 (2017): 24-26.

- (con José Javier Marzal Felici) «Miradas convergentes: la fotografía y sus interpretaciones en humanidades y ciencias sociales», Fotocinema: revista científica de cine y fotografía 10 (2015): 3-7. (Coordinación del Monográfico).

- «La historia de la fotografía ante un nuevo tiempo cultural: Reflexiones para un encuentro interdisciplinar», Fotocinema: revista científica de cine $y$ fotografía 10 (2015): 9-25.

- «Una intersección de interpretaciones sobre fotografía: entre la disparidad epistemológica y la diversidad de aproximaciones», Ayer 96 (2014): 185-199.

- «Ángel Fuentes y su legado en la preservación del patrimonio fotográfico», Fotocinema: revista científica de cine y fotografía 9 (2014): 4-6.

- «De la foto al fotograma. Relaciones entre cine y fotografía en la Argentina (1840-1933). Andrea Cuarterolo», Secuencias: Revista de historia del cine 39 (2014): 137-140.

- «Una revisión del valor cultural de la tarjeta postal ilustrada en el tiempo de las redes sociales», Fotocinema: revista científica de cine y fotografía 2 (2011): 3-18.

— "Mirant a la història i aprenent a experimentar amb nous mètodes», Educació i història: Revista d'història de l'educació 15 (2010): 19-39.

— "La imagen de la infancia en la fotografía del siglo XIX», Peonza: Revista de literatura infantil y juvenil 50 (1999): 31-36.

- "Contemplando el mundo a la luz de una linterna mágica», Peonza: Revista de literatura infantil y juvenil 49 (1999): 21-27.

- «Imágenes fotográficas y estrategias de opinión pública: los viajes de la Reina Isabel II por España (1858-1866)», Reales Sitios: Revista del Patrimonio Nacional 139 (1999): 2-15.

- «13 Rue del Percebe o la persistencia de una tradición en la representación simultánea», Trasdós: Revista del Museo de Bellas Artes de Santander 1 (1999): 49-54.

- «Pere Mata, difusor de la invenció de la Fotografia en els orígens de L'Estat lliberal», KESSÉ. Cercle d'Estudis Històrics i socials Guillem Oliver 25 (1998): 7-10.

- «Mil cosas: La fotografía, un instrumento científico y un hallazgo liberal», Historia 16264 (1998): 88-97.

— «William Atkinson (1825-1907) The Alar del Rey-Reinosa railway», History Of Photography 2 (1997): 170-171.

- «La historiografía española y los debates sobre la fotografía como fuente histórica», Ayer 24 (1996): 91-112. 
- «La Nueva Memoria: la Fotografía frente a la descripción dibujada o la paradoja de Turpin», Papel Alpha 2 (1996): 135-153, 217-226 (versión en inglés).

— «La Insinuación del "Realismo”". Una Aproximación a la representación gráfica de la violencia en el siglo XIX», Componente Nort, 1 (1996): 52-57.

- «Una nueva mirada a las linternas mágicas y otros espectáculos ópticos», Imatge 5 (1993): 39-42.

- «The daguerreotype as a photometer: Spanish Technical Innovations In Photography's Beginnins», The Daguerreian Annual (1993): 110-115.

- «La Imagen Como Fuente de la Historia Contemporánea», Revista de historia de la fotografía española 3 (1991): 23-28.

- «L'Espagne face au Défi Technologique et Culturel de la Photographie. 1839-1840», Photoresearcher 3 (1991): 33-40.

- «Fotografías Turísticas o el Descubrimiento de lo Esperado, Nueva Imagen 15 (1991): 20-21.

- «La veracidad fotográfica y sus límites imaginarios: análisis de los mitos visuales y tecnológicos del objeto fotográfico", Kalathos: Revista del seminario de arqueología y etnología turolense 9-10 (1989-1990): 287-312.

\section{Nota de los autores}

Francisca Comas Rubí es doctora en Ciencias de la Educación (2000), profesora titular de Teoría e Historia de la Educación de la Universidad de las Islas Baleares y miembro del Grupo de Estudios de Historia de la Educación de la UIB. Ha centrado su investigación en la historia de la educación en la época contemporánea, concretamente en temáticas relacionadas con la historia de la infancia y juventud, los movimientos de renovación pedagógica contemporáneos y la fotografía como fuente para la historia de la educación. Ha participado como investigadora en proyectos desarrollados en el marco de planes nacionales $\mathrm{I}+\mathrm{D}+\mathrm{I}$ sobre movimientos juveniles, y dirigido como investigadora principal tres proyectos $\mathrm{I}+\mathrm{D}+\mathrm{I}$ sobre la fotografía como fuente para la historia de la educación y uno sobre culturas y prácticas escolares en el siglo XX, este último en proceso de ejecución. Ha formado parte, como secretaria y tesorera, de la Junta directiva de la SEPHE (Sociedad para el Estudio del Patrimonio Histórico-Educativo) entre los años 2004 y 2012, y desde el año 2005 es vicepresidenta de la Societat d'Història de l'Educació dels Països de Llengua Catalana. Actualmente imparte docencia en el Grado de Pedagogía y en el Máster de Intervención Socioeducativa en Menores y Familia. 
Bernat Sureda Garcia es doctor en Pedagogía por la Universitat de Barcelona. Catedrático de Teoría y Historia de la Educación de la UIB. Su campo de investigación es la historia de la educación. Es investigador principal del Grup d'Estudis d'Història de l'Educació de la UIB. Ha participado como investigador en diversos proyectos financiados en convocatorias competitivas. Es director de la revista Educació $i$ Història y miembro del consejo editorial de la revista History of Education \& Children's Literature (HECL).

Ha sido vicerrector de la UIB y presidente del Consejo Escolar de les Illes Balears. Últimamente, junto con su grupo de investigación ha trabajado en la utilización de las fotografías como fuente para la historia de la educación. Fruto de estas investigaciones son los últimos trabajos publicados: «The photography and propaganda of the Maria Montessori method in Spain (1911-1931)» (2012); «Pedagogical innovation and music education in Spain: Introducing the Dalcroze method in Catalonia» (2014) o "Album photographique scolaire, histoire et configuration de l'identité des établissements scolaires: le cas du collège Sant Josep Obrer de Palma» (2016), publicados junto con otros miembros del GEDHE. 